\title{
Hospital management teams - reflections on organizational and medical specialization cultures
}

\author{
Elina Viitanen*1, Lauri Kokkinen ${ }^{2}$, Hannu Puolijoki ${ }^{3}$ \\ ${ }^{1}$ School of Health Sciences, University of Tampere, Tampere, Finland \\ ${ }^{2}$ Finnish Institute of Occupational Health, Tampere, Finland \\ ${ }^{3}$ Etelä-Pohjanmaa Hospital Districht, Seinäjoki, Finland
}

Received: September 15, 2015

DOI: $10.5430 /$ jha.v5n1p90
Accepted: November 19, 2015 Online Published: December 1, 2015

URL: http://dx.doi.org/10.5430/jha.v5n1p90

\begin{abstract}
Although hospital management is studied in several branches of science, scarcity of studies investigating management team work in hospitals exist. The purpose of this paper was to study managers' understanding concerning the role of management team work in specialized health care, as well as management team work methods within the different activity areas in a hospital and in the operational units within their domain. A total of 54 interviews of activity area managers and operational unit managers in one Finnish hospital district in 2007-2008 was analyzed using data-driven content analysis. Work of all management teams focused on financial and operative issues. However, different management teams used different working methods, which implicates the existence of medical specialization-specific work subcultures within a shared organizational culture. The psychiatric activity area appeared the most active and the most future-oriented, whereas the activity area of operative specializations seemed the most defensive, and the activity area of conservative specializations was businesslike and unfocused as regards the future. These differences were portrayed in the teams' inner dynamics and interaction practices. Activity area work methods did not directly transfer to those of the unit-level management teams. We conclude that management teams may not be optimally used as a forum for strategic issues or innovation throughout hospital organizations and more research is needed in order to better understand the connections between management team work, organizational culture and medical specialization culture.
\end{abstract}

Key Words: Management teams, Specialized health care, Specialist fields, Hospital activity areas, Operational units

\section{INTRODUCTION}

International management literature deems large hospitals complex, difficult-to-manage organizations, ${ }^{[1-3]}$ which cannot be organized without consideration for the wider health care context. ${ }^{[4]}$

In addition to its formal juridical and administrative organization, a hospital is also run by a normative organizational structure, in which the institutionalized rules and methods of operation of the hospital come into play. ${ }^{[5]}$ Typically, hospitals have a multi-tier hierarchy of management levels, as well as highly specialized work units built around strong professional experts. ${ }^{[6]}$ Varying orientations between different professions may cause communication problems and friction. ${ }^{[7-9]}$

Medical specializations greatly determine the structure of large hospital organizations. Specializations function as the basis for the operational organization and the different activity areas. Operational units are usually grouped by these medical specializations. Hospital managers discuss specializations without making the distinction between organizational structures and medical terms. For examples "gastroenterology" may refer to either a medical specialization or structural

*Correspondence: Elina Viitanen; Email: elina.viitanen@staff.uta.fi; Address: School of Health Sciences, University of Tampere, Tampere, Finland. 
unit within the hospital organization. ${ }^{[10]}$

Hospitals are also path-dependent on their history. They are in a constant state of dynamic evolution and their history partially defines their current operation and operational culture. ${ }^{[11]}$ Culturally, hospitals can be broken down into several subcultures. ${ }^{[12]}$ Organizational culture relates to the assumptions, values, attitudes and beliefs that are shared among significant groups within an organization. ${ }^{[13,14]}$ Culture concerns the common, accepted ways of doing things within an organization, as well as the shared, individual ways of each of its members of making sense of the organization. Organizational culture varies across the hospital organization and some of this variation is attributable to the variety of organizational characteristics and measures of performance. ${ }^{[15]}$ In a hospital, subcultures may be found in, for example, specialist fields and management team operations. ${ }^{[10]}$

One British study focused on the NHS's 189 acute hospital trusts and the nearly 900 managers running them. Describing senior management team culture, more than half of the trusts were identified as dominant clan culture types, whereas 29 per cent were dominant rational, 11 per cent were developmental, and only 6 per cent were hierarchical in their culture. ${ }^{[15]}$ A hospital may be considered a complex, dynamic and adaptive system, in which no one is fully able to control the system or foretell the outcomes of decisions. ${ }^{[16,17]}$ Hospitals represent culturally and structurally divided operational fields, and are very challenging to manage as a whole. To better manage such an entity, one may take advantage of arenas that bring together people from different sub-groups. In a hospital, these include management teams on different hierarchical levels.

\section{Conceptual framework}

In this study, a management team denoted a group of people from a given organization, and was composed of managers, experts, human resource (HR) and other interest group representatives, brought together by a manager for regular planned meetings, to discuss matters concerning the hospital's operations. A management team's main role is to support the manager in his/her work, for which he/she is personally responsible. Management teams are continuous in their operations and are not formed to carry out only a single project.

Recent research on top management teams (TMT) has demonstrated that they can have a profound impact on the strategic direction and performance of their organizations. The majority of TMT research has brought the importance of management team composition to light, and has employed various versions of demography theory. ${ }^{[18]}$ Demography the-

Published by Sciedu Press ory suggests that the composition of TMTs, with regards to various demographic characteristics (e.g. age, tenure, functional and educational background), may explain the collective behavior of management teams. ${ }^{[19-21]}$ Recent studies on TMTs have also demonstrated that the management team culture strongly influences the behaviors, attitudes and values of the individuals of an organization ${ }^{[22]}$ and impacts the organization's performance. ${ }^{[23]}$

At its best, management team work helps broaden the participants' perspective on the organization's operations and helps them understand the significance of decisions relating to their own field as regards the organization's main task and the financial success of the business. ${ }^{[24-26]}$ A functional management team actively participates in carrying out and monitoring the organization's strategy. ${ }^{[27,28]}$ A well-functioning management team is also a strong decision-making body ${ }^{[29-31]}$ and increases the organization's innovativeness. ${ }^{\text {[32-34] }}$

In a hospital, management team membership is mainly based on the person's hierarchical or professional position within the organization, and not, for instance, on personal qualities, or an analysis of the talent or knowhow the management team lacks, or the ideal combination of demographic factors. Management teams are composed with reverence to representation. ${ }^{[35]}$ They vary greatly in how they operate. The most distinctive are the professional and executive management teams and their ways of realizing the organization's strategy differ considerably from those of others. ${ }^{[27,36]}$

The aim of this study is to add to the understanding of the role that management team work plays in hospital management. The study focuses on activity areas and operational unit management teams' tasks as a part of running a hospital, as well as on management team practices. Our research questions are the following: 1) How do management team members perceive the operation of their management team? 2) How do management team practices in different activity areas and operational units differ from each other?

\section{METHOD}

\subsection{Data collection}

The Specialized Medical Care Act (1062/1989) requires that Finnish municipalities provide specialized health care for their residents. For this purpose, each municipality is associated with one of 20 hospital districts, which each have a central hospital. Hospital districts collect a client fee, but the majority of the services are paid for by the municipalities, that is, they are tax-funded. The highest decision-making power in hospital districts lays with a political organ.

The present study is based on semi-open interviews of managers who are members of management teams. The inter- 
views were about management team operations. The data were collected from the activity areas (conservative, operative, psychiatric) of one hospital district and the operational units subordinate to them, and concerned the subject of their management teams. The conservative activity area included the operational units of internal medicine, neurology, lung diseases, physiatry and rehabilitation, cancer, skin diseases and geriatrics, and covered altogether 390 employees. The operative activity area included the operational units of surgery, orthopedics, gynecology, anesthesia, intensive care, pediatrics, ophthalmology, otorhinolaryngology and oral diseases, covering altogether 660 employees. The third activity area, psychiatrics, included the operational units of adult and elderly psychiatry, child and adolescent psychiatry and collaborative psychiatric outpatient clinics, covering altogether 370 employees.

Interview participation was voluntary. The interviews were themed, and they addressed, for example, management team structure, work methods, interaction, time management, the role of the chairperson, and management team decisionmaking. At the end of the interviews, the interviewees took time to think about how they could improve their management team.

The data included 54 manager interviews, which were conducted individually. The interviews targeted a management team chairperson and team members in five activity areas and in five operational units. They were conducted during the fall of 2007 and the spring of 2008, and lasted approximately 45-60 minutes. All interviews were recorded and transcribed as 15-25 typed pages.

The interviewees were 23 head physicians, 6 head nurses, 7 trustees, 9 nurse managers, and 9 personnel members. Of those interviewed, 21 were men and 33 were women. The interviews and the analysis were conducted by the same two researchers throughout the study. Because management team membership was connected to the person's formal position in the organization, the representativeness of management teams turned out to be quite large. The size of management teams varied from 8 to 15 participants.

\subsection{Data analysis}

For the first research question, we utilized all 54 interviews, and for the second research question, we used the interviews of the management team members from the conservative, operative and psychiatric activity areas and the management team member interviews of the four operational units subordinate to the aforementioned activity areas. These interviews amounted to 44. Approximately half of the members in each management team were interviewed, taking into considera- tion the representativeness of the groups.

We applied data-driven content analysis to the research questions. ${ }^{[37]}$ First, the data was read through several times to obtain a general view. The first stage concerned looking for subject-matter relating to management team operations. The analysis unit was a sentence or a complete thought. The original quotes were chosen word for word, after which they were paraphrased, grouped and labeled with words descriptive of content. During the grouping phase, we looked for similarities and differences. Expressions with similar content were grouped into sub-categories, and further, through abstraction, into umbrella categories and uniting categories. The categories were named according to their content. ${ }^{[37,38]}$

\section{RESULTS}

The management teams dealt with a large variety of different subjects. Some of these were on the agenda each time, some followed an annual schedule, and some were situational. The majority of the subjects at hand were informative, routine and recurrent in nature. The atmosphere at the meetings was, according to the interviewees, mainly positive and dialogic. New management team members were not briefed on management team work beforehand. There were no known common goals for the management team's work, nor did team members come together to assess the success of their work. The managers interviewed were members of one or more management teams and some of them were chairpersons in their own specialist field's management team.

\subsection{Management team tasks}

The data showed that hospital management teams had several different tasks. A summary of these tasks is presented in Table 1.

Table 1. Management team tasks

- Sharing information
- Increasing interaction
- Forming a common consensus
- Division of tasks and duties relating to operative management
- Assisting and coordinating future-planning
- Making Decisions
- Increasing commitment to organization
- Offering development opportunities for managers

As information channels, the management teams worked both vertically and horizontally. The chairperson was able to use the management team to distribute information and the members were able to receive it. The management team meeting acted as a forum for raising issues. In addition, management team members received information from other sub-units in their own operational unit.

ISSN 1927-6990 E-ISSN 1927-7008 
Management team meetings had varying levels of success as interaction forums. The chair-person's role was seen as highly important in achieving successful interaction. Members reported that management teams were "the image of their chairperson". All members had the opportunity to speak but not everyone felt the need to do so. Managers (mostly doctors) spoke, and deputies (mostly nurses) remained quiet, although they were familiar with the subjects at hand. HR representatives did not speak unless spoken to. Participant interest was mainly focused on the subject that they themselves represented. In activity area management team meetings in particular, members were mainly only interested in matters concerning their own specialist area or specialist areas close to their own.

Management team meetings were used for forming a common consensus and agreement on how orders from higher up, directions, or some task otherwise deemed important, would be carried out in practice.

Management team meetings laid foundations and discussed coordination for future plans, talked about patient queues or the need for stand-ins and assigned individual planning assignments to members of the management teams. Strategic planning had little prominence in management teams' routine operations.

Personnel issues came up in management team interviews as small snippets of discussion concerning employee wellbeing at work, appointments, applications for further training, workforce sufficiency, and recruitment. No shared or planned HR management views were brought up in management team interviews.

The interviews depicted the management team's role as a decision-making body as somewhat ambiguous in terms of actual decisions being made in the meetings and whose decisions these were. Interviewees mainly spoke of decisions made by the management team, but for most of them - though not for everyone - it was clear that the operational unit manager was responsible for the decisions. The decision-making process was very much portrayed as a search for consensus. Open disputes were rare. Chairpersons in particular emphasized the present unity and good atmosphere of their own management teams. Consensus was sought through conversations in which every voice counted and compromises were made. Meetings in which no consensus was reached were rare. Once a decision was jointly made, everyone committed to it, especially in top-tier management teams, in spite of possible differing personal opinions. Management team work was seen to possess a quality of committing a person to joint decisions.

\subsection{Management team's significance for managerial work}

Table 2 presents the most significant matters that the managers brought up in the interviews when discussing the management teams' significance for their own work.

Table 2. Management teams' significance to managerial work

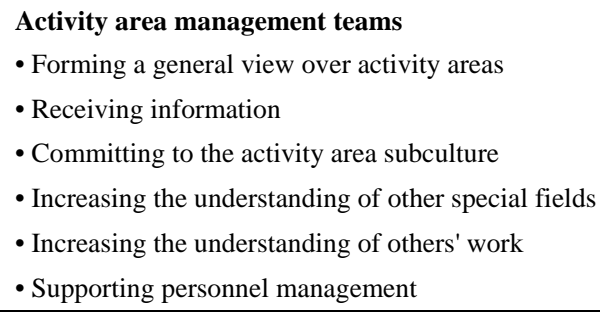

Members of activity area management teams who were managers stressed the importance of information flow, as well as having a bigger picture of the activity area and the specialist areas operating within them. In operational unit management team interviews, the managers emphasized features that supported their own managerial work and its improvement. Joint activities and peer support were also deemed important.

\subsection{Activity area management team practices}

The managers in the management teams of all three activity areas were of the opinion that representation was key to information sharing. All teams received the same information

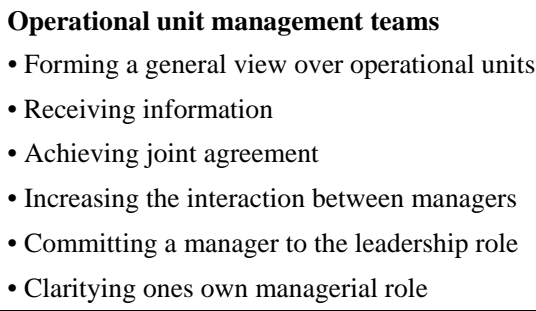

at the same time. All three management teams considered their chairperson to be communicative and responsive to the management team.

There were certain distinctions in the way management teams operated. These were mainly visible in the managers' descriptions of group atmosphere, interaction within the group, the manager's attitude toward management team members, inclination towards development, and joint activities. Table 3 contains descriptions of the different work cultures distinctive to different activity areas' management teams.

The psychiatric activity area clearly stood out from the other 
two by virtue of its own strong remit strategy, clarity of decision-making, inclination for change and openness, and its dialogic working method. The management team strove for development and innovation with an eye on the future. There was less focus on results or financing than in the conservative and operative activity areas. In both of these two activity areas, the strategy seemed unclear. There were differences between the two management teams' working methods. In the operative activity area, the emphasis was on the participants standing up for their own subspecialist areas, headed by large specialist fields such as surgery and orthopedics. The conservative activity area's internal working methods were characterized by sticking to facts, the importance of information sharing, the management team's taciturnity, and established working methods.

\subsection{Operational unit management team practices}

Table 4 presents the work cultures of the four operational units' management teams. Two of the units belonged to the operative activity area, one to the conservative and one to the psychiatric.

The same practices appeared to be largely in use in the opera- tional units, as in the activity area management teams above them. Observing finances and profitability was emphasized. In all the operational units, as well as in the activity areas above them, the principle of the management team's function appeared unclear. There was also some confusion about decision-making in all but two operational units. Matters concerning the whole hospital district were not discussed in unit-level management team meetings and were mainly only reported.

Each operational unit management team had its own internal interaction practices which generally did not follow those of the activity area management teams. The management teams that shared the largest amount of management team practices were the surgery activity area and unit-level management teams, which emphasized a similar specialist territorial ideology to that of the operative activity area management team. The lung diseases unit, which is a part of the conservative activity area, appeared the most active and open to change. The child psychiatry unit had a drive for change in its communicative practices and was innovative and dialogic, and was in this way similar to the psychiatric activity area, but disjointed and chaotic in its other practices.

Table 3. Activity area management team work cultures

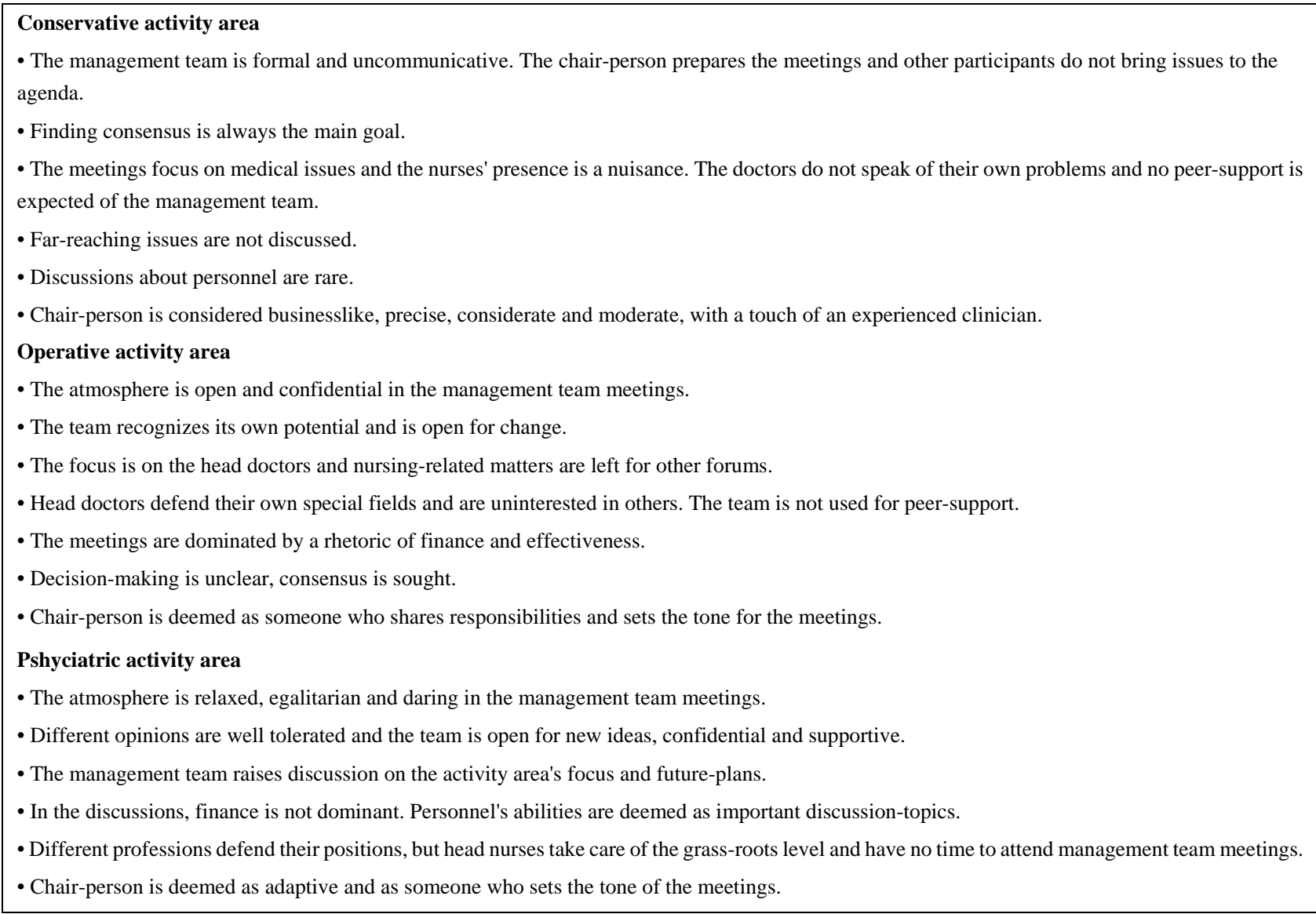


Table 4. Operational unit management team work cultures

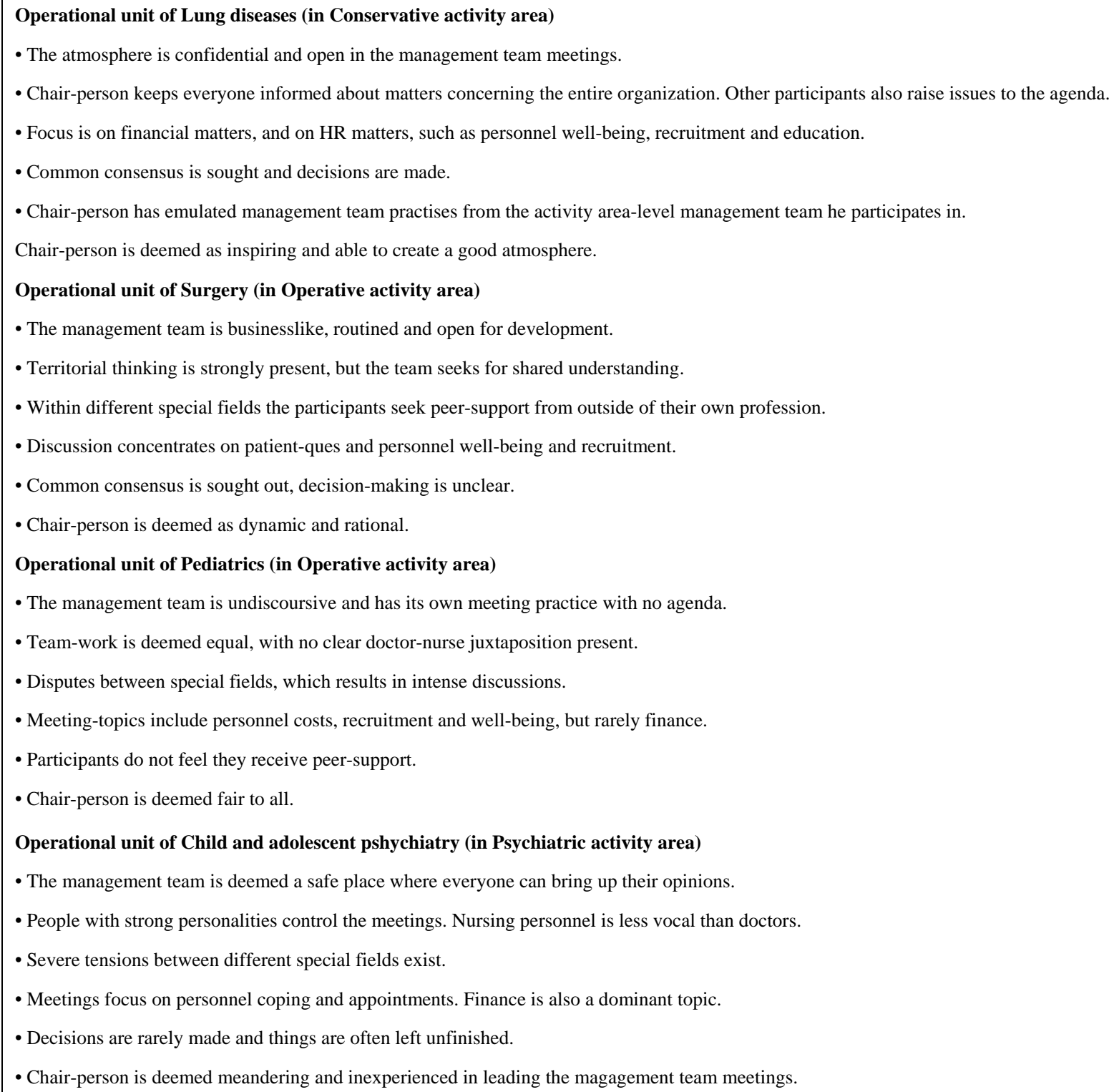

\section{DISCUSSION}

The aim of the study was to observe management team work in specialized health care, and to determine the differences in the ways different management teams work. Table 5 presents the summary of our findings.

The management teams we studied were quite large. Large groups may not be ideal for information processing or innovation, but they do increase the likelihood of the management group's heterogeneity. On the other hand, heterogeneity may decrease the group's productivity if the group is unable to reach a satisfactory level of consensus. ${ }^{[39]}$ The most crucial part is the interaction between team members and the shape that this takes. ${ }^{[40,41]}$ Hospitals typically have a consensus-

Published by Sciedu Press seeking work culture, which also became evident during this study. In addition to a positive outlook, it may also lead to the selection of neutral topics for the management team's perusal which do not lead to open, progressive discussion.

The results indicate that no new ideas or development projects were hatched in the management teams. This may be a result of their afore-mentioned large size. The lack of brainstorming decreases information processing and information use and finally affects the hospital's openness to development. ${ }^{[19,42]}$ According to previous literature, the bestfunctioning management teams have members with different levels of experience, skills and personal outlooks, and their power is unevenly distributed. Management teams such as 
this are better equipped to promote strategic change in hospitals and to improve certain figures depicting patient-care efficiency. ${ }^{[27,43]}$

It has also been stated that multi-talented management teams are openly motivated to learn new things (such as financial ad- ministration data systems and data administration) related to the development of a hospital's strategic development. ${ }^{[44,45]}$ According to criteria based on experience and profession, all the management teams in this study had equal opportunity to actively participate in developing the hospital's operation.

Table 5. Summary of findings

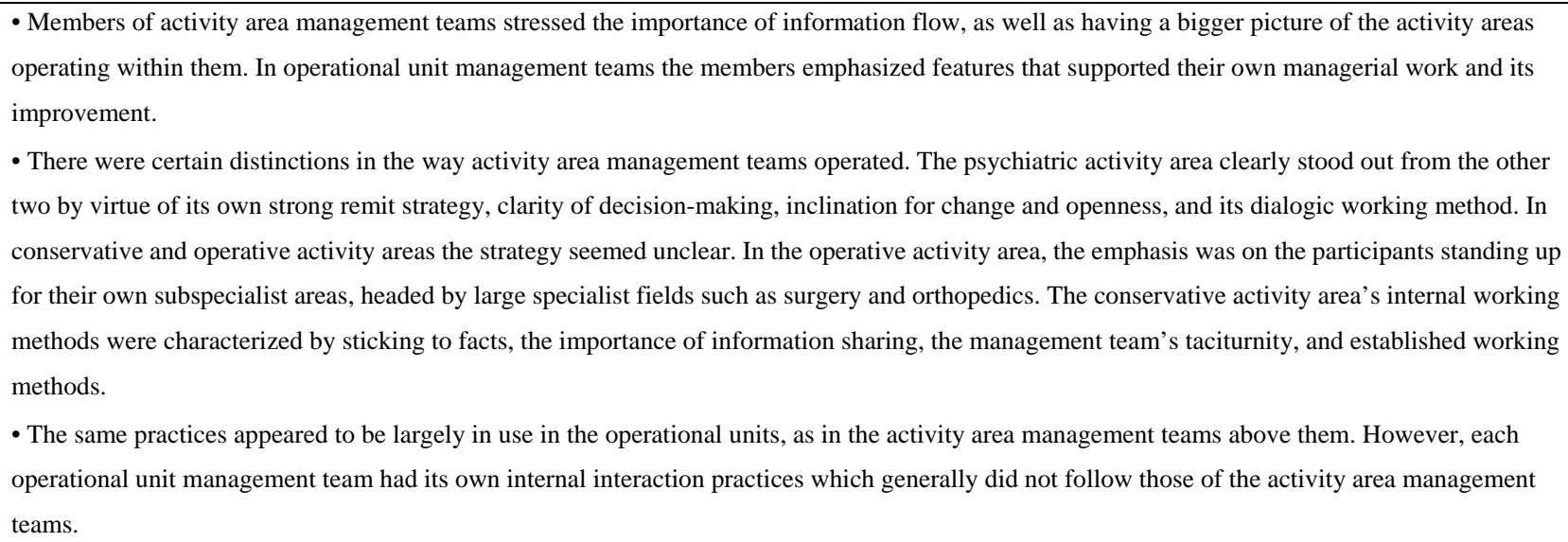

The data showed several tasks assigned to the management teams. They formed an excellent channel for the trickling up or down of information. Regular meetings brought methods to managerial work. Management team membership increased commitment to the decisions already made and to the "subculture" of management. Middle-managers in particular saw the management teams of their respective operational units as the most important managerial tool at their disposal. The management team directly above a manager's own operational unit was not deemed important. There is a contradiction here, in that the managers largely dealt with matters in their own level's management team meetings, which they were informed of and tasked with in upper-level management team meetings. In addition, the results indicate that chairpersons modeled their own actions on those of their predecessors and the chairpersons in upper-level management teams. Practices such as this have been previously stated to stem from the tradition of professional management. ${ }^{[10]}$

The results show that management teams served the operative management and coordination of everyday functions of a hospital, which consisted of multiple hierarchal levels and several highly specialized units. Certain significant management areas, such as strategic remit management, HR management and overall future-orientation, were rarely addressed in management team meetings. The study raises the question of where exactly these management areas materialize in hospitals, and whether they materialize enough at all.
The hospital district's shared strategy remained secondary in all management teams and the strategy concerning the team's own field appeared unclear in the operative and conservative activity area.

Although management team work is a common practice in public hospitals, the teams' tasks and goals appeared largely unclear. This may be partly due to the fact that new team members are not given any orientation towards the responsibilities and liabilities they have as team-members. Similarly, the hospital's strategy, along with its outlined issues and goals, quickly vanished on the way down in management teams along the hospital hierarchy. Unit-level management team tasks appeared to consist of organizing daily management and solving everyday issues.

Even if the significance of management team work for managing a hospital remained weak, as the results indicate, we must acknowledge the importance that the teams had for single solitary managers' work and for improving their own leadership. Management team work served to broaden horizons and to help see one's own work as part of a larger whole. Management teams functioned as arenas for outlining a common vision within a unit and for outlining the tasks and responsibilities for operative management.

Management teams had different ways of operating according to remit. The most clearly perceivable were the differences in internal group dynamic and interaction practices. Some of the management teams' practices may have differed 
due to the team members' backgrounds in specialized health care, specialist fields, and their subcultures. ${ }^{[15]}$

In a study by Virtanen, different specialized health care managers noted that people with professional backgrounds in a certain medical specialization and who worked in the organizational unit adjacent to that specialization had certain common traits unique to their specialization background, and that they might differ greatly from people with other medical specialization backgrounds. The difference was apparent in behavior and it was clearly perceivable among doctors; less so among nurses. Concerning surgeons, the image was one of straightforward, sometimes exuberant, people with an appreciation of themselves and of practical surgical experience. Of interns, the image was one of slow-moving, thoroughly analytical people who made decisions and acted in a calm and relaxed manner, all the while retaining their own opinions. At an equal distance from both these groups were the psychiatrists, who were considered to be "different" and impossible to define using the same criteria. ${ }^{[10]}$

These differences were also apparent in management team interaction and internal dynamics. The operative management activity area's management team had different subspecialization managers who jealously guarded their own territory, and managers who had a distinct preference for procedures, ${ }^{[8,9]}$ whereas the conservative activity area management team members could be described as composed, businesslike, and contemplative. Members of psychiatric management teams often brought to the team's discussion an open and multivalued discourse concerning nearly everything that happened within the team's remit. The meetings were meandering in nature, but often the open interaction and everyone being heard produced a good atmosphere; one in which innovation was also possible. ${ }^{[31]}$

In the light of this study, it would appear that the surgical specialists and their representatives had a stronger tendency to transfer their own work methods to management team work than the other specialists and their representatives. The surgical unit was governed by the same territorial mentality and the fight for one's own field found in non-surgical units, and in the activity area above it. In future studies, it would be pertinent to pay more attention to the transfer of work methods from upper to lower management levels, because the work culture a management team adopts has been found to affect health care organization effectiveness in hospitals, as well as in primary health care. ${ }^{[15,46,47]}$

Literature on hospital management team operation from a medical specialization perspective is scarce, so it is difficult to say how strong the subcultures found actually are and whether or not they have characteristics which, in the long run, could either hinder or promote management team work. In this study, we only looked at four different operational units and to make a conclusive judgment, data from additional units from different activity areas would have been necessary.

The research was carried out in one hospital and the results are not directly applicable more generally. This would require additional data for comparison from other hospitals and the work of their management teams. Also, as certain aspects of organizational culture and professional culture may by highly embedded in certain national context, ${ }^{[48]}$ the study needs to be replicated outside its Nordic context. However, as recent leadership research has demonstrated, studies conducted in several Western countries have been highly consistent with research outcomes from China and other Asian countries, ${ }^{[48-50]}$ indicating the importance of organizational and professional cultures on the global scale. Also, as such, the one-on-one interviews of 54 managers from different specialist fields offer a broad view of management teams' roles in hospitals, and the parallel analysis carried out by two researchers improves the reliability of the study.

From a hospital management perspective, we should pay more attention to management team operation, their tasks, and the way in which a hospital's top management directs its management teams. As management team work methods manifest different features of specialized health care, the management teams do not necessarily operate in the same way. Managers at different organizational levels have different personal and organizational goals and needs. ${ }^{[17]}$

Managing diversity in management team work is a challenge for the hospital management. Quinn et al. ${ }^{[51]}$ state that managers must simultaneously tackle multiple different roles and event horizons, which they need to understand and accept. Management team chairpersons would be hard pressed to utilize the different work cultures found in different groups while reflecting on improving their own management teams' work.

Management team work could be improved by clarifying operational goals and informing everyone in the organization about them, as well as by refining management team dynamics by consciously dissolving routinized work methods, avoiding unnecessarily routine handling of matters, enhancing meeting techniques, and by adding future orientation to the teams' work. Management team leadership and decisionmaking could also be improved by applying different models of team work. ${ }^{[52]}$ 


\section{REFERENCES}

[1] Begun J, Zimmerman B, Dooley K. Health Care Organizations as Complex Adaptive Systems. In S. Mick and M. Wyttenbach (Ed.), Advances in Health Care Organization Theory. San Fransisco, CA: Jossey-Bass; 2003. 253-288.

[2] Sweeney K. Emergence, complexity and organizational development. In E. Peck (Ed.), Organizational Development in Healthcare. Approaches, innovations, achievements. Abington, UK: Radcliffe Publishing Ltd; 2005. 143-166.

[3] Davidson D, Peck E. Organizational development and organizational design. In K. Walshe and J. Smith (Ed.), Healthcare Management New York, NY: Two Pen Plaza; 2006. 343-363.

[4] Shortell SM, Kalunzny A. Organization Theory and Health Services Management. In S.M. Shortell and A.D. Kalynzny (Ed.), Health Care Management, Organization Desing and Behavior. New York, NY: Thomson Delmar Learning; 2006. 5-41.

[5] Kokkinen L. Työntekijät julkisten sairaaloiden rakennemuutostarpeiden synnyttäjinä ja rakennemuutosten seurausten kokijoina (Employees create needs for and experience the effects of structural changes in public hospitals). Tampere, Finland: Tampere University Press; 2013. PMid: 23658426.

[6] DiMaggio PJ, Powel WW. The Iron Gage Revisited. Institutional Isomorphism and Collective Rationality in Organizational Fields. American Sosiological Review. 1983; 48(2): 147-160. http://dx .doi .org/10.2307/2095101

[7] de Bruijn H. Managing professionals. New York, NY: Routledge; 2011.

[8] Degeling P, Kennedy J, Mill M. Mediating the cultural boundaries between medicine, nursing and management- the central challenge in hospital reform. Health Service Research. 2001; 36(2): 36-48. http://dx.doi.org/10.1258/0951484011912519

[9] Sexton B, Thomas E, Helmreich R. Error, stress, and teamwork in medicine and aviation: cross sectional surveys. British medical journal. 2000; 320: 745-749. PMid: 10720356. http://dx.doi.org $/ 10.1136 / \mathrm{bmj} .320 .7237 .745$

[10] Virtanen JV. Johtajana sairaalassa. Johtajan toimintakenttä julkisessa erikoissairaalassa keskijohtoon ja ylimpään johtoon kuuluvien lääkäri- ja hoitajataustaisten johtajien näkökulmasta (Being a manager at the hospital setting. Managerial environment in a public hospital providing specialized care from the perspective of a physician and nurse managers in middle and upper management). Turku, Finland: Uniprint; 2010.

[11] Holden LM. Complex adaptive systems: concept analysis. Journal of Advanced Nursing. 2005; 52(6): 651-657. PMid: 16313378. http://dx.doi.org/10.1111/j.1365-2648.2005.03638.x

[12] Bate P. Changing the culture of a hospital: from hierarchy to networked community. Public Administration. 2000; 78(3): 485-512. http://dx.doi.org/10.1111/1467-9299.00215

[13] Davies HTO, Nutley SM, Mannion R. Organizational culture and health care quality. Quality in Health Care. 2000; 9(2): 111-119. PMid: 11067249. http://dx.doi.org/10.1136/qhc.9.2.111

[14] Scott JTR. Does Organizational culture help to explain heath care performance A review of the evidence. Journal of Health Service Research \& Policy. 2003; 8(2): 105-117. PMid: 12820673. http://dx.doi.org/10.1258/135581903321466085

[15] Davies HTO, Mannion R, Jacops A, et al. Exploring the relationship between Senior Management Team Culture and Hospital Performance. Medical Care Research and Review. 2007; 64(1): 46-65. PMid: 17213457. http://dx.doi.org/10.1177/10775587062 96240

[16] Anderson RA, MC Daniel Jr RR. Managing Health Care Organizations: Where Professionalism Meets Complexity Science. Health
Care Management Review. 2000; 25(1): 83-96. http://dx.doi.o rg/10.1097/00004010-200001000-00010

[17] Rouse WB. Managing Complexity. Disease Control as a Complex Adaptive System. Information-Knowledge-System Management. 2000; 2(2): 143-165.

[18] Pfeffer J. Organizational demography. In L.L. Cummings and B.M. Staw (Ed.) Research in organizational behavior. Greenwich, CT: JAI Press; 1983. 299-357.

[19] Hambrick D. Fragmentation and the Others Problems CEOs have with their Top Management Teams. California Management Review. 1995; 37(2): 110-127. http://dx.doi.org/10.2307/41165801

[20] Hambrick D. Upper Echelons Theory: An Update. Academy of Management Review. 2007; 32(2): 334-343. http://dx.doi.org/10. 5465/AMR . 2007.24345254

[21] Carmeli A, Schaubroek J. Top management team behavioral integration, decision quality and organizational desline. The Leadership Quarterly. 2006; 17(5): 441-453. http://dx.doi.org/10.1016 /j.leaqua.2006.06.001

[22] Prenestini A, Calciolari S, Lega F, et al. The relationship between senior management team culture and clinical governance: Empirical investigation and managerial implications. Health Care Management Review. 2015; 40(4): 313-323. PMid: 25083858. http: //dx.doi.org/10.1097/HMR.0000000000000035

[23] Zhang X, Li N, Ullrich J, et al. Getting Everyone on Board: The Effect of Differentiated Transformational Leadership by CEOs on Top Management Team Effectiveness and Leader-Rated Firm Performance. Journal of Management. 2015; 41(7): 1898-1933. http: //dx.doi.org/10.1177/0149206312471387

[24] Finkelstein S, Hambrick D. Strategic Leadership: Top Executives and their Effects on Organization. Minneapolis, MN: West Publishing Company; 1996.

[25] Hambrick D, Aveni D. Top team deterioration as part of the downward spiral of large corporate bankruptcies. Management Science. 1992; 38(10): 1445-66. http://dx.doi.org/10.1287/mnsc. 38 .10 .1445

[26] Papadakis V, Barwise P. How much do CEO and top managers matter in strategic decision-making? British Journal of management. 2002; 13(1): 83-95. http://dx.doi.org/10.1111/1467-8551.0022 4

[27] Naranjo-Gil D, Hartman F. How Top Management Teams Use Management Accounting Systems to Implement Strategy. Journal of Management Accounting Research. 2006; 18(1): 21-53. http://dx.doi.org/10.2308/jmar.2006.18.1.21

[28] Roberto M. The stable core and dynamic periphery in top management teams. Management Decision. 2003; 41(1): 120-131. http: //dx.doi.org/10.1108/00251740310457560

[29] Goll I, Rasheed A. The Relationships between Top Management Demographic characteristics, Rational Decision Making, Environmental Munificence and Firm Performance. Organization Studies. 2005; 26(1): 999-1023. http://dx.doi .org/10.1177/0170840 605053538

[30] Greve H, Mitsuhashi H. Power and Glory: Concentrated Power in Top Management Teams. Organization Studies. 2007; 28(8): 1197-1221. http://dx.doi.org/10.1177/0170840607075674

[31] Zorn T, Tompson G. Communication in top management teams. In L. Frey, D. Gouran and M. Poole (Ed.), The handbook of group communication theory and research. Thousand Oaks, CA: SAGE Publishing; 1999. 253-272.

[32] Barkema H, Shvyrkov O. Does Top management team diversity promote or hamper foreign expansion? Strategic Management Journal 2007; 28(2): 663-680. http://dx.doi.org/10.1002/smj.604 
[33] Miller C, Burke L, Glick W. Cognitive diversity among upper echelon executives. Implications for strategic decision processes. Strategic Management Journal. 1998; 19(1): 3958. http://dx.doi.org/10.1002/(SICI) 1097-0266(199801 ) $19: 1<39:$ :AID-SMJ932>3.0.CO;2-A

[34] Hambrick D, Mason P. Upper Echelons. The Organization as a Reflection of Its Top Managers. Academy of Management Review. 1984; 9(2): 193-206.

[35] Viitanen E, Virtanen JV, Kokkinen L, et al. Sairaalan johtoryhmät kaipaavat kehittämistä (How effective are hospital management teams?). Suomen Lääkärilehti. 2011; 66(5): 373-377.

[36] Naranjo-Gil D, Hartman F. Control of top management teams in Spanish hospitals. Research executive summary series. 2011; 7(1): $1-9$.

[37] Krippendorf K. Content analysis. An introduction to its methodology. Thousand Oaks, CA: SAGE Publications; 2004.

[38] Cavanagh S. Content analysis: concepts, methods and applications. Nurse Research. 1997; 4(3): 5-16. http://dx . doi .org/10.7748 /nr1997.04.4.3.5.c5869

[39] Hollingshead AB, Wittenbaum GM, Paulus PB. A Look at Groups From the Functional Perspective. In M.S. Poole and A.B. Hollingshead (Ed.), Theories of Small Groups. Interdisciplinary Perspectives. Thousand Oaks, CA: SAGE Publications; 2005. 21-62. http: //dx.doi.org/10.4135/9781483328935.n2

[40] Scott CW, Shanock LR, Rogelberg SG. Meeting at work: Advancing the theory and practice of meetings. Small Groub Research. 2012; 43(2): 127-129. http://dx.doi.org/10.1177/1046496411429 023

[41] Hirokawa RY, De Gooyer DJ Jr, Valde KS. Characteristics of Small Group Communication. In L. Henman (Ed.), Small Group Communication: Theory \& Practice: An Anthology. Oxford, UK: Oxford University Press; 2003. 148-157.

[42] Tabak F, Bharat J. Predicting Hospital Innovativeness: an exploration of the perceived organizational context. Journal of Applied Management Studies. 2000; 9(2): 217-233. http://dx.doi.org/10.10 $80 / 713674363$

[43] Smith A, Houghton SM, Hood JN, et al. Power relationship among top managers: Does top manager power distribution matter for organizational performance. Journal of Business Research. 2006; 59(5): 622-629. http://dx.doi.org/10.1016/j.jbusres. 2 005.10 .012

[44] Hartman F, Naranjo-Gil D. Control of top management teams in Spanish hospitals. Research executive summary series. 2011; 7(1): 1-9.

[45] Smaltz DH, Sambamurthy V, Agawal R. The Antecendents of CIO Role Effectiveness in Organizatios: An Empirical Study in the Healthcare Sector. IEEE Transactions on engineering management. 2006; 53(2): 207-222. http://dx.doi.org/10.1109/TEM. 200 6.872248

[46] Lovelace K. Multidisciplinary Top Management Teamwork: Effects of Local Health Department Performance. Journal of Public Health Management Practice. 2001; 7(1): 21-29. PMid: 11141620. http://dx.doi.org/10.1097/00124784-200107010-00006

[47] Mannion R, Davies HTO, Marshall MN. Cultural characteristics of high and low performing hospitals. Journal of Health Organization and Management. 2006; 19(6): 431-439. PMid: 16375066. http://dx.doi.org/10.1108/14777260510629689

[48] Kirkman BL, Chen G, Farh JL, et al. Individual power distance orientation and follower reactions to transformational leaders: A cross-level, cross-cultural examination. Academy of Management Journal. 2009; 52(4): 744-764. http://dx.doi.org/10.5465/A MJ . 2009. 43669971

[49] Chen G, Tjosvold D, Liu C. Cooperative goals, leader people and productivity values: Their contribution to top management teams in China. Journal of Management Studies. 2006; 43(5): 1177-1200. http://dx.doi.org/10.1111/j.1467-6486.2006.00633.x

[50] Wu JB, Tsui AS, Kinicki AJ. Consequences of differentiated leadership in groups. Academy of Management Journal. 2010; 53(1): 90-106. http://dx.doi.org/10.5465/AMJ . 2010.48037079

[51] Quinn RE, Faerman SR, Thompson MP, et al. Becoming a master manager. A competing values approach. New Jersey, NJ: Willey; 2001.

[52] Arendt LA, Priem RL, Ndofor HA. A CEO-Adviser Model of Strategic Decision Making. Journal of Management. 2005; 31(5): 680-699. http://dx.doi.org/10.1177/0149206305279054 